\title{
VERGİ HUKUKUNDA TARH ZAMANAŞIMI
}

\author{
Time Limits for Levy in Tax Law
}

Adil NAS*

\section{ÖZET}

Vergi borcunu sona erdiren nedenlerden birisi de zamanaşımıdır. Zamanaşımı, alacak hakkının, bir süre kullanılmaması sebebiyle dava edilebilme yeteneğinden yoksun kalınması manasına gelir.

Zamanaşımı vergi alacağını ortadan kaldırır. Bundan dolayı re'sen göz önünde tutulması gerekir. Vergi hukukunda iki tür zamanaşımı vardır. Bunlar tarh ve tahsil zamanaşımıdır. Tarh zamanaşımı verginin tarh edilerek mükellefe tebliğ edilmesiyle ilgili bulunmaktadır. Vergi tarhında zamanaşımı süresi kural olarak vergi alacağının doğumunu takip eden takvim yılından başlamak üzere beş yıldır. Tarh zamanaşımı ile ilgili bu genel kural yanında VUK'nda özel zamanaşımı süreleri de öngörülmüştür. Veraset ve intikal vergisi ile Emlak vergisindeki özel tarh zamanaşımı süreleri, zamanaşımı kavramına uygun düşmemektedir.

* Dr., Niğde Vali Yard.Niğde Üniversitesi İ.İ.B.F. (adilnas@hotmail.com). 
Anahtar Sözcükler: Zamanaşımı, Tarh zamanaşımı, Tahsil zamanaşımı, Zamanaşımının durması, Zamanaşımının kesilmesi

\section{ABSTRACT}

One of the reasons for the termination of a tax debt is the statute of limitations. The statute of limitations means being unable to sue because of failing to use the right to tax in a timely manner.

Time limits eliminate the tax debt and therefore must be considered sua sponte. There are two types of time limits in tax law: these are the time limit for imposition and the time limit for collection. The time limit for imposition is related to notifying the taxpayer of the imposition of the tax and is, as a rule, five years following the first calendar year of the start of the tax. In addition to this general rule, for the time limit for imposition, there is also the special time limitation envisaged in the tax law. The special time limit in precedent tax for inheritance and property taxes does not fit within the concept of the statute of limitations.

Keywords: Statute of limitations, Time limits for tax levy, The time limits for collection, The stopping of timeout, Tolling of the statute of limitations

\section{GİRIŞ}

Vergi alacağını kaldıran önemli sebeplerden birisi de zamanaşımıdır. Vergi alacaklısı olan devleti vergi alacağını takip etme ve harekete geçirme konusunda itici bir güç olan zamanaşımı, vergilendirmenin temel öğeleri arasındadır ve süre geçmesi suretiyle vergi alacağının kalkması sonucunu doğurur.

Bireylerin sosyal ve ekonomik durumlarını etkileyecek keyfi uygulamalara neden olunmaması için vergiyi doğuran olay, matrah, oran, tahsil, yaptırım gibi vergilendirmenin temel öğelerinden olan zamanaşımının da yasalarda gösterilmesi gerekir. 
Vergi hukukunda zamanaşımının kabul edilmesinin temel nedeni kamu yararıdır. Zamanaşımının hukuki anlamda alacaklıyı cezalandırmak amac1 yoktur. Devletin vergi alma yetkisinin zamanaşımı süreleri ile sınırlandırılması vergiden doğan hukuki ilişkinin uzun zaman askıda kalmasını önler; çünkü vergi idaresi alacaklarını izleme konusunda daha dikkatli olma zorunluluğunu duyar. Böylece kamu yararı kadar tek tek kişilerin yararı da korunmuş olur. Zamanaşımının kamu yararı bakımından doğurduğu sonuçlardan biri yargı organlarını yükünü azaltıcı etkisidir. Ayrıca gerektireceği giderler yönünden de devletin takip ve tahsili uzun süre gecikmiş vergileri izlemesi uygun değildir. Vergi borçlarının uzun süre ödenmeden kalması yükümlülerin ticari güvenlikleri bakımından sakıncalıdır. Defter ve belgeler uzun zaman içinde yitirilmiş olabileceğinden ispat zorlukları doğurabilir; zamanaşımı bu zorlukları kaldırır ${ }^{1}$.

Yukarıda belirtilen yararlarına karşılık zamanaşımının sakıncaları da vardır. Her şeyden önce vergide adalet ve eşitlik ilkelerine zarar verebilir. Başka bir deyişle ödevlerini düzenli yapan ve vergisini zamanında ödeyen mükellefler aleyhine, daha az dikkatli ya da namuslu mükellefler lehine, bir ayırım ortaya çıkarmasındadır. Zira, borcunu ödeyen dürüst ve dikkatli mükellefler, kendileri kadar dürüst ve dikkatli olmayan başkalarının belli süreler, sonra, zamanaşımı nedeniyle, vergi borçlarından kurtulduklarını görerek vergi ile ilgili olarak olumsuz bir düşünceye kapılabilirler ${ }^{2}$. Ayrıca zamanaşımı vergi kaçakçılığını teşvik edebilir. Özellikle kayıt dışı ekonominin yaygın olduğu ülkelerde, devletle vergisel irtibat kurmadan faaliyete geçen, bu faaliyetini sürdüren, vergi ödeme niyeti olmayan kişiler zamanaşımı süresinin dolmasıly kayıt dışı faaliyetlerinden dolayı ödüllendirilmiş olurlar. Yıllarca bu şekilde faaliyetini sürdürmüş olan kişi, faaliyeti tespit edildiği zaman yalnız zamanaşımı süresi içindeki faaliyetinden dolayı vergi ödemek zorunda kalır. Ancak böyle bir işletmenin faaliyetinin ve kazancının

\footnotetext{
${ }^{1}$ Öncel Mualla. Kumrulu Ahmet. Çağan Nami. (2008). Vergi Hukuku. (15. bs.). Ankara: Turhan Kitabevi. s. 132.

${ }^{2}$ Uluatan Özhan. (1994). Vergi Hukuku. (2. bs.). Ankara: Adım Yayıncılık. s. 152.
} 
boyutlarının ne olduğunun tespiti hemen hemen mümkün değildir. Çünkü bir yandan defter ve belge yokluğu, diğer taraftan kişinin servetinin ve bu serveti ne zaman ne şekilde elde ettiğinin (özelikle servet beyanı yoksa) tespitinin güçlügü vergi incelemesini büyük ölçüde kısıtlar. Dolayısılla kayıt dışı faaliyette bulunan yükümlü zamanaşımı süresi içinde de gerçeğe uygun vergilendirilmemiş olur ${ }^{3}$.

Diğer hukuk dallarında olduğu gibi vergi hukukunda zamanaşımının faydaları zararlarına göre daha ağır bastığı için kabul edilmiştir.

Zamanaşımı kanun tarafından tayin edilmiş (belirtilmiş) şartlar altında ve belli bir süre içinde alacaklının hareketsiz kalması sonucu alacağın ifasını isteme yetkisinin sona ermesidir ${ }^{4}$. Diğer bir tanımla zamanaşımı alacak hakkının, belli bir süre kullanılmaması nedeniyle "dava edilebilmesi" niteliğinden yoksun kalınmasını ifade eder; sürüp giden eylemli durumu, kesin ve dokunulmaz hukuki duruma çeviren bir kurumdur 5 .

Özel hukukta zamanaşımının alacaklı yönünden hükmü, onun alacağını borçludan isteyememesi, yani istem ve dava haklarını kaybetmesi şeklinde ortaya çıkar. Zamanaşımı alacak hakkının bizzat kendisini etkilemeyip sadece ondan çıkan istem (talep) ve dava haklarını ortanda kaldırdığından dolayıdır ki, borç yine devam eder; fakat borçlu zamanaşımına dayanarak edimini ifadan kaçınma imkanını elde etmiş olur; yani alacaklarının ifa istemine karşı zamanaşımı def'inde bulunarak savunma yapabilir. Borçlu, zamanaşımı def'ini ileri sürmedikçe hakim bunu re'sen dikkate alamaz ${ }^{6}$.

Yukarıda belirtildiği gibi, özel hukuk alanında zamanaşımı alacağın kendisini değil, onun talep edilebilirliğini ortadan kaldırır; buna karşılık, hak düşümü süresi hakkın özünü ortadan kaldırır. Vergi hukuku alanında,

${ }^{3}$ Yılmaz Kazım. (1994).ABD’de Tarhiyat ve Ceza Zamanşımı. Vergi Dünyası. Sayı 155. s.25.

${ }^{4}$ Akıntürk Turgut. (2006). Borçlar Hukuku.(20.bs.). İstanbul: Beta. s. 183.

${ }^{5}$ Anayasa Mahkemesinin 15.10.2009 tarih ve E: 2006/124 K: 2009/146 say1lı Kararı 08.01.2010 tarih ve 27456 sayılı RG'de yayımlanmıştır.

${ }^{6}$ Akıntürk, s.188. 
zamanaşımından söz edilmekle birlikte, zamanaşımı hak düşümüne denk sonuçlar yaratır. Zamanaşımı vergi alacağının kendisini ortadan kaldırır. Dolayısıyla, zamanaşımının, vergi hukuku alanında, görevden ötürü (re'sen) göz önünde tutulması gerekir? .

\section{TARH ZAMANAȘIMI KAVRAMI}

Vergi hukukunda iki tür zamanaşımı vardır. Bunlar tarh ve tahsil zamanaşımıdır. Tarh zamanaşımı 213 sayılı VUK'nunda tahsil zamanaşımı ise 6188 sayılı AATUHK'da düzenlenmiştir. Tahsil zamanaşımı ödeme vadesine ulaşmış bulunan verginin tahsil edilebilirlik süresi ile ilgilidir. Tarh zamanaşımı ise verginin tarhedilerek yükümlüye tebliğ edilebilmesiyle ilgilidir. Tarh zamanaşımı süresi içinde tebliğ edilemeyen vergi zamanaşımına uğrar ${ }^{8}$.

VUK'nun 113 ve 114. maddelerinde düzenlenmiş bulunan tarh zamanaşımı, yazında tahakkuk zamanaşımı, tebliğ zamanaşımı veya vergilendirme zamanaşımı kavramı şeklinde de ifade edilmektedir ${ }^{9}$. Sözü edilen maddelerde bu zamanaşımının tarh, tahakkuk, tebliğ veya vergilendirme zamanaşımı olarak adlandırılacağına ilişkin olarak, kanunun doğrudan zamanaşımını düzenleyen bu maddeleri arasında bir hüküm bulunmamaktadır. Ancak, mücbir sebeple ilgili VUK'un 15. maddesinde tarh kavramına yer verilmiştir. Öte yandan aynı kanunun 114. maddesinin birinci fikrasında da “...tarh ve tebliğ edilmeyen... ifadesi mevcuttur. Vergileme süreci içinde, tarh işleminin tebliğinden sonra verginin tahakkuk etmesinde artık idarenin herhangi bir mükellefiyeti bulunmamaktadır. Burada zamanaşımına yer verilmesinin esas nedeninin idarenin tebligat dahil vergilendirme işlerini süresinde yaparak savsaklamaması olduğu dikkate alındığında, bu zamanaşımını

7 Kaneti Selim. (1986/1987). Vergi Hukuku. İstanbul: İstanbul Üniversitesi Hukuk Fakültesi Yayınları. s. 124.

${ }^{8}$ Kaneti, s. 124.

9 Şenyüz Doğan. Vergilendirme Sürecinde Zamanaşımı Kavramı Üzerine Terminolojik Bir Değerlendirme; Tebliğ Zamanaşımı, Yaklaşım Dergisi. 2008/3 (183). 31.08 .2010 http://www.yaklasim.com/mevzuat/dergi/makaleler.pdf. 
tarh zamanaşımı şeklinde ifade etmenin daha doğru olabileceği kanaatindeyiz ${ }^{10}$.

\section{TARH ZAMANAŞIMI SÜRESİ}

\section{ESAS KURAL}

Vergi Usul Kanunu'nun 114. maddesi uyarınca, vergi alacağının doğduğu takvim yılını takip eden yılın başından başlayarak beş yıl içinde tarh ve mükellefe tebliğ edilmeyen vergiler zamanaşımına uğrar. Buna göre tarh zamanaşımı süresi beş yıldır. VUK'undan önce yürürlükte bulunan 5432 sayılı VUK'nunda bu süre 3 yıl kaçakçılık suçlarında 5 y1l olarak öngörülmüştü.

Hemen belirtelim ki zamanaşımı hesap döneminin takvim yılı ve özel hesap dönemi olmasına göre değişebilmektedir. Hesap dönemi takvim yılı olanlarda vergi alacağının doğduğu takvim yılının başından itibaren beş yıl geçmekle zamanaşımı süresi dolarken, özel hesap döneminde hesap döneminin kapandığı yılı izleyen yılın başından itibaren beş yıl geçmekle zamanaşımı süresi dolmaktadır ${ }^{11}$.

Zamanaşımı süresinin işleyebilmesi için vergi alacağının doğumu esastır. Vergiyi doğuran olay VUK'nun 19. maddesinde de düzenleme konusu yapılmıştır.

Buna göre "vergi alacağı vergi kanunlarının vergiye bağladıkları olayın meydana gelmesi veya hukuki durumun tamamlanması ile doğar." Tarh ve tebliğ gibi usul ile ilgili işlemlerin yapılması soyut vergi borcunun doğuş zamanı bakımından etkili değildir; yükümlülük vergiyi doğuran olayla birlikte ortaya çıkar. Vergiyi doğuran olay, yükümlülerin vergi yasalarında gösterilen vergi konuları ile bir ilişki ve bağl1lık kurmaları anlamına gelir ${ }^{12}$.

\footnotetext{
${ }^{10}$ Mutluer M. Kamil. (2006). Vergi Genel Hukuku. İstanbul: İstanbul Bilgi Üniversitesi Yayınları. s. 148.

${ }^{11}$ Özyer Mehmet A. (2008). Vergi Usul Kanunu Uygulaması. İstanbul: Hesap Uzmanları Derneği. s. 202.

12 Öncel, Kumrulu, Çağan, s. 134.
} 
Vergi tarhında zamanaşımı süresi kural olarak beş yıldır. Vergi doğuran olayı izleyen y1ldan başlamak üzere beş y1l içinde verginin mükellefe tarh ve tebliğ edilmesi gerekir. Danıştay'a göre zamanaşımı süresinin en son gününün tatil gününe rastlaması, zamanaşımının uzaması sonucunu doğurmaz ${ }^{13}$. Danıştay'ın bu görüşü, vergi sürelerinin sona ermesinin tatil gününe rastlaması halinde, bu sürelerin ilk mesai günün sonuna kadar uzayacağı ile ilgili genel kurula uygunluk göstermemektedir. Bundan dolayı Danıştay'ın kararını yerinde görmüyoruz. Tarh zamanaşımının süresinin son gününün tatil gününe rastlaması durumunda, bu sürenin tatil gününü izleyen ilk günü mesai saati sonuna kadar uzayacağı ile ilgili VUK'nun 114. maddesine bir fikra eklenmelidir. Yapılacak böyle bir düzenleme ile bu konudaki tartışmalar sona erecektir.

Tarh zaman aşımının incelenmesi ile ilgili talepler verginin tahsili aşamasında da yapılabilir. Başka bir deyişle amme alacağının tahsili aşamasında da tarh zamanaşımı incelenebilirr ${ }^{14}$.

Yukarıda belirtildiği gibi verginin tarhında zamanaşımı süresi kural olarak beş yıl olmakla beraber değişik vergi yasalarında özel kurallara yer verilmiştir. Bu özel kurallar aşağıda ele alınmıştır.

\section{TARHI ZAMANAŞIMI SÜRESİ ILE ILGILİ ÖZEL DURUMLAR}

\section{A. VERASET VE INTTIKAL VERGISINDE}

Veraset ve intikal vergisinde zamanaşımının başlangıcı için vergiyi doğuran olayın tarihi değil, mükellefiyetin doğduğu zaman esas alınmıştır ${ }^{15} .7338$ sayılı Veraset ve İntikal Kanunu'nun 20. maddesine ilişkin gerekçede, vergi alacağının, normal olarak ya maddi bir olay olan

13 Danıştay 4. Dairenin 17.12.1996 tarih ve E: 1995/609 K: 1996/5649 sayılı Kararı. 06.09.2010, http://www.danıstay.gov.tr/kerisim/ozet.jsp?ozet=metin\&dokid.pdf.

${ }^{14}$ Danıştay İçtihatları Birleştirme Kurulu'nun 03.04.1987 tarih ve E:1986/3, K: 1987/1 say1lı Kararı. 31.08.2010, http://www.danistay.gov.tr/kerisim/ozet.jsp?ozet= metinAd.pdf.

${ }^{15}$ Kırbaş Sadık (1995). Vergi Hukuku. Ankara: Siyaset Kitabevi. s. 119. 
ölüm hadisesine veya hukuki durumun tekemmülüne bağlı olduğu, bu madde ile mükellefiyet başlangıcının, ölüm ve ivazsız iktisabın tarihi değil de beyanname tarihi olarak belirlenmesindeki amacın sadece verginin zamanaşımına uğramasının engellenmesi olduğu belirtilmiştir.

Veraset ve intikal vergisi mükellefiyeti; beyanname verildiği taktirde, beyanname tarihinde başlar (VIVK.m.20,a). Bu durumda tarh zamanaşımı genel kurallara göre tespit edilir. Ancak verilen beyannamede gösterilmeyen mallar ile beyanname verilmeyen durumlarda intikal eden malların mükellefiyeti idarece tespit olunduğu tarihte başlamaktadır (VIVK.m.20,b). Bu durumda zamanaşımı tespitin yapıldığı yılı izleyen yılın başında başlaması gerekir. Burada özellik şudur; her ne kadar vergiyi doğuran olay ölüm yada ivazsız intikal ise de, beyannamenin verilmemesi yada eksik verilmesi halinde, vergiyi doğuran olayın gerçekleşmesi bakımından yeterli görülmemekte, idarenin bilgisi dışında bırakılan vergi konusu malların vergi idaresi tarafından öğrenilmesi zamanaşımının işlemesi bakımından esas alınmaktadır ${ }^{16}$. Nitekim konuyla ilgili Danıştay vermiş olduğu bir kararda ${ }^{17}$ "veraset ve intikal vergisi beyannamesinin verilmediği hallerde zamanaşımının intikal eden malların idarece tespit olunduğu tarihten itibaren başlayacağı" şeklinde görüş belirtmiştir.

Veraset ve intikal vergisinde, mükellefiyetin idarece tespit edildiği tarihte başlaması şeklindeki düzenlemesi bu verginin zamanaşımına uğramasını büyük ölçüde önlemekle beraber, intikal olayı beyan ve idarece tespit edilinceye kadar verginin doğmamasına yol açmaktadır. Ayrıca bu süre içinde matrahlar ve ödenecek vergi tutarları enflasyon nedeniyle reel olarak küçülmekte bu küçülmenin telafisi olmadığı gibi geç beyanın gecikme faizine veya gecikme zamanına yada usulsüzlük cezası dışında herhangi bir cezaya konu olmaması durumu doğmaktadır ${ }^{18}$.

\footnotetext{
${ }^{16}$ Kaneti, s. 126.

17 Danıştay 7. Dairenin 17.11.1986 tarih ve E: $1985 / 2$, K: $1986 / 2528$ sayılı Kararı. 31.08.2010, http://www.danıstay.gov.tr/kerisim/ozet.jsp?özet=metin=dokid.pdf.

18 M. Tahir UFUK, Veraset ve İntikal Vergisinde Zamanaşımı, Yaklaşım Dergisi. 31.08.2010, http://www.yaklasim.com/mevzuat/dergi/makaleler.pdf.
} 
Tarh zamanaşımı, terekenin tahriri, defter tutma ve resmi tasfiye hallerinde mahkemece bu işlemlerin tamamlandığ 1 tarihi izleyen yılın başından itibaren işlemeye başlar (VIVK, m.20,c). Belirtmek gerekir ki, mirası reddetmeyen varisler hakkında vergi yükümlülüğü doğabilmesi için, tespit edilen alacak ve borçlar karşısında vergiye tabi bir matrahın bulunması gerekir ${ }^{19}$. Vergiye tabi bir matrahın bulunması halinde takip eden yılın başında tarh zamanaşımı başlatılmalıdır.

\section{B. EMLAK VERGISİ}

Emlak vergisindeki tarh zamanaşımı veraset ve intikal vergisindekine benzerlik göstermektedir. Emlak vergisi beyannamesinin süresinde verilmesi halinde tarh zamanaşımı genel kurallara göre tespit edilir $^{20}$. Buna göre tarh zaman aşımı emlak beyannamesi verildiği yılı izleyen takvim yılından itibaren beş yıldır.

Bina ve arazi vergilerinde zamanaşımı süresinin başlangıcı açısından bir özellik vardır. Bildirim dışı kalan bina ve arazinin vergi ve cezalarında zamanaşımı, bu bina ve arazinin bildirim dışı bırakıldığının, idarece öğrenildiği tarihi takip eden yılın başından itibaren başlar (EVK.m.40). 4751 say1lı Kanunla ${ }^{21}$ 09.04.2002 tarihinde Emlak Vergisi Kanunun 40. maddesinde yapılan değişikliğe kadar "bildirim dişı" yerine "beyan dışı" kavramı kullanılmaktaydı. Bildirim dışı beyan dışına göre daha geniş bir kavramı içermektedir.

Emlak Vergisi Kanunu'nun 40. maddesindeki bina ve arazi vergilerinde zamanaşımı süresinin başlangıcı ile ilgili düzenleme, zamanaşımı kavramının amacına uygun düşmemektedir. Çünkü zamanaşımı toplumun geçmiş olaylar bakımından belirsiz zamanlara kadar tedirgin olmaması için konulmuştur. vergi kaçakçılığını önleme

\footnotetext{
${ }^{19}$ Danıştay 7. Dairenin 18.04.1986 tarih ve E: 1986/1175, K: 1986/1307 sayılı Kararı. 31.08.2010, http://www.danıstay.gov.tr/kerisim/ozet.jsp?özet=metin=dokid.pdf.

${ }^{20}$ Emlak alım vergisi beyannamesinin süresinde verilmesi halinde $213 / 114$ ve 374 madde hükümlerinin uygulanması gerekir. (Danıştay 3. Dairenin 11.03.1986 tarih ve E: 1986/28, K: 1986/799 say1lı Kararı. 31.08.2010, http://www.danıstay.gov.tr/ kerisim/ozet.jsp?özet $=$ metin=dokid.pdf.).

${ }^{21} 4751$ sayılı Kanun 09.04.2002 tarihinde ve 24721 sayılı RG' de yayımlanmıştır.
} 
çabasının bir sonucu olarak görülen emlak vergisinin 40. maddesindeki hükümlerin değiştirilmesi ve vergi kaçakçılığının yeterli vergi idaresi ile önlenmesi uygun düşmektedir ${ }^{22}$.

\section{DAMGA VERGISII}

Damga vergisinde vergiyi doğuran olay, bu kanun kapsamında olan kağıtların düzenlenmesidir. Damga vergisinde tarh zamanaşımı, damga vergisine tabi kağıtların düzenlediği tarihi izleyen yıldan itibaren beş yıldır. Bu normal tarh zamanaşımı süresidir.

Ayrica VUK'nun 114. maddesinde Damga Vergisinde tarh zamanaşımı ile ilgili özel bir düzenleme yer almaktadır. Buna göre "Damga Vergisine tabi olup vergi ve cezası zamanaşımına uğrayan evrakın hükmünden tarh zamanaşımı süresi dolduktan sonra faydalanıldı̆̆ 1 taktirde, sözü edilen evraka ait vergi alacağ1 yeniden doğar."

Damga vergisindeki tarh zamanaşımı ile ilgili özel düzenlemeyi, zamanaşımının yeniden başlaması olarak değil vergiyi doğuran olayın ikinci kez ortaya çıkması, başka bir ifade ile ayrı bir vergi alacağının doğmas1 olarak düşünmek gerekir. Zira yeniden bu evraktan yararlanılması halinde eğer vergi oranları değişmişse yeniden yararlanılan tarihte geçerli olan vergi uygulanacak veya vergiye tabi olmaktan çıkmışsa vergi tarh edilmeyecektir ${ }^{23}$.

\section{TASFIYEYE GIIREN KURUMLARDA}

Kurumlar Vergisi Kanunu'nun 17. maddesi uyarınca, her ne sebeple olursa olsun, tasfiye haline giren kurumların vergilendirilmesinde hesap dönemi yerine tasfiye dönemi geçerli olur.

Tasfiye, kurumun tasfiye girmesine ilişkin genel kurul kararının tescil edildiği tarihte başlar ve tasfiye kararının tescil edildiği tarihte sona erer. Başlangıç tarihinden aynı takvim yılı sonuna kadar olan dönem ile

\footnotetext{
${ }^{22}$ Erginay Akif. (1988). Vergi Hukuku. Ankara: Turhan Kitabevi. s. 96.

23 Özyer, s. 218.
} 
bu dönemden sonraki her takvim yılı ve tasfiyenin sona erdiği dönem için ilgili takvim yılı başından bitiş tarihine kadar olan dönem bağımsız bir tasfiye dönemi sayılır (KVK.m.17).

Bağımsız tasfiye dönemi başladığı takvim yılında bittiği taktirde genel zamanaşımı kuralı geçerli olur. Başka bir deyişle zamanaşımı bakımından burada bir özellik yoktur. Zamanaşımı süresi işleyen takvim y1lından başlayarak beşinci yıl sonunda dolmuş olur.

Ancak bağımsız tasfiye dönemi birden fazla dönemde gerçekleştiğinde, bütün dönemlere ait zamanaşımı, tasfiyenin sonuçlandığ 1 y1lı izleyen takvim yılından başlar ve beşinci yıl sonunda dolar ${ }^{24}$

\section{E. ŞARTA BAĞLI MUAFIYET VE ISTISNALARDA ZAMANAŞIMI}

Şarta bağlı istisna ve muafiyet uygulamaları sonucu kısmen veya tamamen alınmayan vergilere ilişkin zamanaşımı süresi, istisna ve muafiyet şartlarının ihlal edildiği tarihi takip eden takvim yılı başından başlar (VUK.114). Buna göre şarta bağlı muafiyet ve istisna hükümlerinin ihlal edildiği tarihi izleyen yıldan başlamak üzere vergi tarhında zamanaşımı süresi beş yıldır.

\section{F. BİRDEN FAZLA TAKVIM YILINA SIRAYET EDEN INSŞAAT VE ONARIM IŞLERINDE}

Birden fazla takvim yılına sirayet eden inşaat (dekepaj işleri de inşaat işi sayılır) ve onarma işlerinde kar ve zarar işin bittiği yıl katı olarak tespit edilir ve tamamı o yılın gelir sayılarak, sözü edilen yıl beyannamesinde gösterilir (GVK.m.42). Yıllara sari inşaat ve onarım işlerini, diğer işlerden ayıran en önemli özellik işlerin bir yıldan fazla sürmesidir.

\footnotetext{
24 Ürel Gürol, Şeker Kenan. (2004). Tarh Zamanaşımı ve Defter, Belge İbrazında Özellikli Durumlar. Yaklaşım Dergisi. 2004/2 (134) 31.08.2010, http://www.yaklasim.com/ mevzuat/dergi/makaleler.pdf.
} 
Bir yıldan fazla süren inşaat ve onarım işlerinde, kar ve zararın işin bitimine bağlanmasının doğal sonucu olarak bu işle ilgili zamanaşımı süresi de işin bittiği yılı takip eden yıldan başlamaktadır. Gelir Vergisi Kanunu'nda bu husus açık olarak ifade edilmemiş olmakla beraber yıllara sari inşaat ve onarım işlerinde zaman aşımının işin bittiği yıldan başlayacağı tartışmasızdır. Zira Vergi Usul Kanunu, zamanaşımını vergi alacağının doğduğu yılı takip eden yılın başından başlattığına ve yıllara sari inşaat işinde de vergi alacağı işin bittiği yılın geliri sayılarak doğduğuna göre zaman aşımı da bu işe ilişkin gelirin beyan edildiği yıldan başlayacaktır ${ }^{25}$.

\section{G. GELİ VERGISII KANUNUNA GÖRE KAYNAKTA KESILEN VERGILER İÇIN ZAMANAŞIMI}

Gelir Vergisi Kanunu'na göre kaynakta kesilerek tahsil edilen vergiler bakımından zamanaşımı başlangıcının tespiti önemlidir. Vergi idaresi vergi sorumluluğunu doğuran olayın verginin kaynakta kesildiği tarihte meydana geleceğini kabul ettiğinden zamanaşımının, verginin kaynakta kesildiği y1lı izleyen takvim yılının birinci gününden itibaren başlaması gerekir ${ }^{26}$. Başka bir deyişle henüz borç doğmadan sorumluluk öngörülen hallerde ve borç olmaksızın nihai bir vergilendirme yöntemi olarak sorumluluğun öngörüldüğ̈ hallerde zamanaşımının başlangıç anı, sorumluluğun yüklendiği ifa anıdır. $\mathrm{Bu}$ durumda vergi idaresi VUK.m.114 gereği, vergi sorumlusunun kestiği vergiyi vergi idaresine yatırması gereken tarihi izleyen takvim yılını takip eden yılın başından başlamak üzere beş yıl içinde işlem yapmaz ise söz konusu vergi alacağ tarh zamanaşımına uğrayacaktır ${ }^{27}$.

\footnotetext{
${ }^{25}$ Özyer, s. 208.

${ }^{26}$ Öncel, Kumrulu, Çağan, s. 134.

27 Akkaya Mustafa. (1997). Vergi Sorumlusunun Vergi Yargis1 ve Vergi İdaresi Karşısındaki Konumu. Ankara Hukuk Fakültesi Dergisi. Cilt 46. Sayı 1-4. s. 204-205.
} 
Danıştay'a göre tevkifata ilişkin zamanaşımı süresinin de kurum kazancının ait olduğu dönemi izleyen yılın başından itibaren başlaması gerekir $^{28}$.

\section{H. VERGİ HATALARINI DÜZELTMEDE ZAMANAŞIMI}

VUK'nun 114. maddesinde düzenlemiş bulunan tarh zamanaşımı süresi kural olarak vergi hatalarını düzeltme zamanaşımında da geçerlidir. Başka bir deyişle vergi hatalarında düzeltme zamanaşımı süresi, vergi alacağının doğduğu yılı izleyen takvim yılının başından başlamak üzere beş yıldır. Nitekim Danıştay konuyla ilgili vermiş olduğu bir kararda ${ }^{29}$ "düzeltme ve şikayet başvurusunun vergi alacağının doğduğu yıldan başlamak üzere beş yıllık süre içinde yapılabileceği” şeklinde görüş ifade etmiştir.

Vergi hatalarını düzeltmede, zamanaşımı süresi kural olarak, vergi alacağının doğumunu izleyen yıldan başlamak üzere beş yıl olmakla beraber, VUK'nun 126. maddesi bazı özel zamanaşımı durumlarını öngörmüştür. Buna göre düzeltme zamanaşımı süresi;

- Zamanaşımı süresinin son yılı içinde tarh ve tebliğ edilen vergilerde hatanın yapıldı $\breve{g}_{1}$,

- İlan yolu ile tebliğ edilip vergi mahkemesinde dava konusu yapılmaksızın tahakkuk eden vergilerde mükellefe ödeme emrinin tebliğ edildiği,

- İhbarname ve ödeme emri ilan yoluyla tebliğ edilen vergilerde 6183 sayılı Kanuna göre haczin yapıldığı,

\footnotetext{
${ }^{28} 1986$ takvim yılına ait kurum kazancı üzerinden Gelir Vergisi Kanunu'nun ilgili y1lda yürürlükte bulunan 3964 sayılı Yasa ile Değişik 75. maddesinin 2. fikrasının (4) işaretli bendi uyarınca hesaplanan menkul sermaye iradı, dağıtılma şartına bağlı olmaksızın tevkifata tabi tutulması gerektiğinden, bu tevkifata ilişkin dönemi izleyen 1.1.1997 tarihinden başlayarak hesaplanması gerekir. (Danıştay 3. Dairenin 13.12.2005 tarih ve E: 2005/1856, K: 2005/2693 sayı1ı Kararı, Kızılot Şükrü. (2008). Danıştay Kararları ve Özelgeler (Muktezalar). Ankara: Yaklaşım Yayınları. s. 642).

${ }^{29}$ Danıştay 7. Dairenin 12.03.1997 tarih ve E: 1995/7184, K: 1997/1046 sayılı Kararı. 31.08.2010, http://www.danıstay.gov.tr/kerisim/ozet.jsp?özet=metin=dokid.pdf.
} 
tarihten başlayarak bir yıldan aşağı olamaz (VUK.m.126). Yukarıda belirtilen üç özel durumda vergi hatalarında düzeltme zamanaşımı süresi 6 y1la kadar çıkabilmektedir.

\section{TARH ZAMANAŞIMININ DURMASI}

Vergi hukukunda zamanaşımı durması, yasada sayılan hallerin ortaya çıkması ile zamanaşımı süresinin işlememesini ifade etmektedir.

Mükellef ile vergi idaresi arasında vergiden kaynaklanan hukuksal ilişki sadece alacak-borç ilişkisi değil aynı zamanda Anayasa'nın 73. maddesinin niteliği gereği bir ödev ilişkisidir. Bu karşl1ıklı ödev gereği, mükelleflerin yükümlülüklerini zamanında, usulüne uygun ve eksiksiz yerine getirmesi, idarenin de vergiyi zamanında tarh, tahakkuk ve tahsil etmesi gerekir.

Zamanaşımı vergi ödevi ilişkisinde yükümlünün çıkarına hizmet ettiği için alacaklının çıkarını korumak üzere zamanaşımı süresinin işlemesini durduran ve kesen nedenler kabul edilmiştir. Gerçekten zamanaşımı alacaklının alacağını izleme konusunda gösterdiği ihmalin sonucudur. Ancak, alacaklı alacağını izlemek üzere bazı işlemler yapmışsa veya alacağını izlemesi bazı durumlar nedeniyle olanak dışı ise salt yasalarda belirtilen sürelerin geçmiş olması alacağın zamanaşımına uğraması için yeterli görülmemiştir ${ }^{30}$.

Vergi dairesince matrah takdiri için takdir komisyonuna başvurulması, zamanaşımını durdurur. Duran zamanaşımı ilgili komisyon kararının vergi dairesine teslimini takip eden günden itibaren kaldığ 1 yerden işlemeye devam eder. Ancak işlemeyen süre her hal ve takdirde bir y1ldan fazla olamaz (VUK.m.114).

Zamanaşımı başvurularının takdir komisyonları tarafından ne kadar bir süre içerisinde çözüme kavuştuştırılacağı ile ilgili 6009 sayılı Kanun ${ }^{31}$ çıkarılıncaya kadar VUK'nunda herhangi bir düzenleme bulunmamaktaydı. VUK'nun 114. maddesinde, matrah takdiri için takdir

${ }^{30}$ Öncel, Kumrulu, Çağan, s. 136.

${ }^{31} 6009$ sayılı Kanun 01.08.2010 tarih ve 27659 sayılı RG'de yayımlanmıştır. 
komisyonuna başvurulmasının zamanaşımını durduracağı ve ilgili komisyon kararının vergi dairesine tevdiini takip eden günden itibaren zamanaşımının işleyeceği ile ilgili bir düzenleme vardı.

Bu durum, idarenin farklı ve keyfi uygulamalarına yol açması, takdir komisyonunda geçen sürenin hukukun genel ilkelerinden hak ve nesafet ilkesini zedelemesi, zamanaşımı müessesesini işlemez hale getirmesi, idarenin geç işleyişinden kaynaklanan gecikme sebebiyle mükelleflerden fazladan gecikme faiziyle karşı karşıya kalmalarını dolayısıyla Anayasa'nın 2. maddesine aykırılık teşkil etmekteydi.

Anayasa Mahkemesi 6009 sayılı Kanundan önce "yürürlükte bulunan VUK'nun 114. maddesindeki, vergi dairesince matrah takdiri için takdir komisyonuna başvurulması zamanaşımını durdurur. Duran zamanaşımı mezkur komisyon kararının vergi dairesine teslimin takip eden günden itibaren işlemeye devam eder" hükmünü Anayasa'ya aykırı bulmuştur. Mahkeme iptal kararını ${ }^{32}$ şu gerekçeye dayandırmıştır.

"VUK'un 114. maddesinin 2. fikrasında, duran zamanaşımının işlemeye başlaması, ilgili takdir komisyonu kararının vergi dairesine tevdiine bağlanmıştır. Takdir komisyonunun kararının tevdii, bu komisyonun çalışma ve kararını oluşturarak tamamlama süresine bağlı olarak değişiklik göstermektedir. $\mathrm{Bu}$ durum, duran zamanaşımının yeniden işlemeye başlama süresini, yükümlü yönünden öngörülemez hale getirmektedir.

Zamanaşımının durma süresinin belirsizliği, makul ve adil bir sürenin bulunmaması, vergi dairesine matrah takdiri için başvurunun sırf zamanaşımını durdurmak için keyfi olarak kullanılmasında güvence sağlamayacağı gibi yükümlüye vergi tahsilatının geciktiği süre kadar gecikme zammı ve faizi uygulanacak olması da yükümlünün vergi yükünü arttırarak haksız sonuçta doğurmasına neden olabilir.

\footnotetext{
${ }^{32}$ Anayasa Mahkemesinin 15.10.2009 tarih ve E: $2006 / 124$ ve K: 2009/146 sayılı Kararı (Bu karar 08.01.2010 ve 27456 sayılı RG'de yayımlanmıştır).
} 
Zamanaşımı hükümlerindeki açılık, sadece zamanaşımı süresinin başlangıç ve bitişinin yasada gösterilmesiyle kendini göstermez. Vergilemede hukuksal kararlılığın sağlanması amaciyla getirilen zamanaşımını durduran nedenlerle, durma süresinin ve duran zamanaşımının işlemeye başlama tarihinin de açık, belirgin, somut ve öngörülebilir olması, keyfiliğe izin vermemesi yasallık ve hukuk devleti ilkesinin gereğidir."

Yasa koyucu da Anayasa Mahkemesinin iptal gerekçisini göz önünde tutarak, çıkardığı 6009 sayılı Kanunla VUK'nun 114. maddesinde değişiklik yaparak matrah takdiri için takdir komisyonlarına yapılacak başvuru sonuçlarının her hal ve takdirde bir yıldan fazla olamayacağını öngörmüştür.

Hemen belirtelim ki VUK'nun 114. maddesi uyarınca zamanaşımının durması için, takdir komisyonlarına yapılan başvuruların matrah takdiri için yapılması gerekir. Emsal bedeli tayini, kıymet takdiri gibi nedenlerle takdir komisyonunu başvuruda bulunulması, matrah takdiri olmayacağından zamanaşımını durdurmamaktadır ${ }^{33}$. Ayrıca tarhiyat öncesi uzlaşmaya gidilmesi halinde de zamanaşımının durması söz konusu değildir ${ }^{34}$.

VUK'nun 377. maddesine göre "vergi idaresi takdir komisyonlarınca vergi tarhının ve takdir olunan matrahlarına karşı vergi mahkemesinde dava açabilir." Ancak vergi idaresi tarafindan yapılan bu başvuruların çoğunda, vergi tarhı zamanaşımı süresi yargı organlarının kararı vergi dairesine gelmeden dolmaktadır. Vergi yarg1sı organlarında geçen süre içinde zamanaşımının işlemeyeceğine dair herhangi bir hüküm yasalarda yer almamaktadır ${ }^{35}$. Fakat buna rağmen uygulamada takdir komisyonu kararlarına karşı idarenin dava açmasından itibaren, yarg1 organlarında geçen sürede zamanaşımı söz konusu olmamaktadır ${ }^{36}$. Biz

${ }^{33}$ Özyer, s. 203.

${ }^{34}$ Danıștay 3. Dairenin 25.03.1999 tarih ve E: 1997/3709, K: 1999/1188 sayılı Kararı. 31.08.2010, http://www.danıstay.gov.tr/kerisim/ozet.jsp?özet=metin=dokid.pdf.

${ }^{35}$ Öncel, Kumrulu, Çağan, s. 132.

${ }^{36}$ Mutluer, s. 152. 
bu uygulamanın verginin yasallığı ilkesine uygun düşmediğini düşünüyoruz. Çünkü verginin yasallığı ilkesi, vergi kurumlarının hukuksal yapısının temel koşulu olup oranının, salınma biçiminin, alınma zamanının yönetim ve yükümlüler bakımından belirginliğine dayanır. Yükümlülere güven veren bu ilke, vergi yönetiminde de kararlıl1k sağlamakta, herkesi eşit biçimde kapsamına alan bir yurttaşlık görevinin göstergesi olmaktadır. Bundan dolayı VUK'nun 114. maddesine eklenecek bir fikra ile vergi idaresi tarafindan matrah takdiri için yargı organlarına başvurulması halinde tarh zamanaşımının duracağı ile ilgili yasal bir düzenleme yapılmalıdır.

Öte yandan, bir vergi tarhının usule aykırı olarak yapıldığının yarg1 organlarınca saptanması halinde, yargıda geçen süre içinde zamanaşımının süresinin duracağına yada kesileceğine ilişkin bir kanun hükmü de yoktur. Buna göre, idare yargı kararına uygun olarak yeniden vergi tarhına giriştiğinde zamanaşımı süresi dolmuş ise artık vergi tarhı yapılamayacaktır ${ }^{37}$. Burada yasal boşluk yanında idarenin verginin tarhı ile ilgili görevlerini iyi bir şekilde yapmaması da söz konusudur.

Tarh zamanaşımını durduran hallerden birisi de mucbir sebeplerdir. VUK'nun 14. maddesi uyarınca mucbir sebeplerden herhangi birinin bulunması halinde bu sebep ortadan kalkıncaya kadar süreler işlemez. $\mathrm{Bu}$ takdirde tarh zamanaşımı işlemeyen süreler kadar uzar. Belirtmek gerekir ki, deprem ve benzeri doğal afetler nedeniyle idare tarafindan yükümlüler lehine getirilen mucbir sebep halinin idare lehine ve idareyi de kapsayacak şekilde uygulanmaması gerekir ${ }^{38}$. Başka bir deyişle mucbir sebep vergi idaresi bakımından VUK'nunda öngörülen tarh zamanaşımı gibi süreye yönelik ve idare lehine uygulama kabiliyeti taşıyan bir düzenleme içermemektedir.

\footnotetext{
${ }^{37}$ Uluatan, s. 153.

38 Danıştay 9. Dairenin 07.06.2007 tarih ve E: 2007/507, K: 2007/230 sayılı Kararı 31.08.2010, http://www.danıstay.gov.tr/kerisim/ozet.jsp?özet=metin=dokid.pdf.
} 


\section{TARH ZAMANAŞIMININ KESILMESİ}

Zamanaşımının kesilmesi demek, kanunda sayılan sebeplerden birinin gerçekleşmesi halinde, zamanaşımının süresinin o ana kadar işlemiş (geçmiş) olan kısmının ortadan kalkması ve sürenin baştan itibaren yeniden işlemeye başlaması demektir. Zamanaşımı durmasında o ana kadar işlemiş olan süre saklı kalırken, kesilmede işlemiş olan süre tamamen, yok olmakta ve süre yeniden baştan işlemeye başlamaktadır ${ }^{39}$.

Tarh zamanaşımının kesilmesi halinde, o ana kadar işlemiş olan süre tamamen yok olmaktadır. VUK'un da vergi cezalarına ait zamanaşımı sürelerinin aksine, tarh zamanaşımının kesilmesi hali düzenlenmemiştir. $\mathrm{Bu}$ yüzden dolan veya herhangi bir sebeple duran zamanaşımının, baştan başlayarak, yeniden işlemesi kural olarak, olanaklı değildir. Bu kuralın istisnası, VUK'nun 114. maddesinde damga vergisi ile ilgili yapılan düzenlemedir ${ }^{40}$.

Daha öncede değinildiği gibi "damga vergisine tabi olup vergi ve cezası zamanaşımına uğrayan evrakın hükmünden tarh zamanaşımı süresi dolduktan sonra yararlanıldığı takdirde ilgili evraka ait vergi alacağı yeniden doğmaktadır (VUK.m.14). Başka bir deyişle tarh zamanaşımı süresi olan beş yıl sıfırdan itibaren başlamaktadır.

\section{TARH ZAMANAŞIMININ SONUÇLARI}

VUK'un daki tarh zamanaşımı süresinin dolmasıyla vergi idaresinin vergiyi tarh ve tebliğ etme yetkisi ortadan kalkar. Mükellefe bu süreden sonra vergi ihbarnamesi ve ödeme emrinin gönderilmemesi gerekir. Zamanaşımının süresinin geçmesiyle vergi alacağı ortadan kalkar.

Verginin eksik tarh edilmesi nedeniyle ikmalen tarhiyata gidilebilmesi ancak zamanaşımı süresinin dolmamasına bağlı bulunmaktadır. Aynı şekilde usule aykırılık nedeniyle yargı kararı ile

\footnotetext{
${ }^{39}$ Akıntürk, s. 187.

${ }^{40}$ Candan Turgut, (2000). Vergilendirme Yöntemleri ve Uzlaşma. Ankara: Yaklaşım Yayınları. s. 197.
} 
kaldırılan bir verginin vergi idaresi tarafından tarh edilebilmesi için zamanaşımı süresinin dolmamış olması gerekir ${ }^{41}$.

VUK'un 138. maddesi uyarınca, vergi incelemesi, neticesi alınmamış hesap dönemi de dahil olmak üzere, tarh zamanaşımı süresi sonuna kadar yapılabilir. Başka bir deyişle tarh zamanaşımı süresi dolduktan sonra idare vergi incelemesi yaptıramaz.

\section{SONUÇ}

Zamanaşımı, alacak hakkının, belli bir süre kullanılmaması nedeniyle dava edebilme niteliğinden yoksun kalınmasını ifade eder; sürüp giden eylemli durumu, kesin ve dokunulmaz hukuki duruma çeviren bir niteliğine sahip bulunmaktadır. Vergi alacaklısı olan devleti vergi alacağını takip etme ve harekete geçirme konusunda itici bir güç olan zamanaşımı, vergilendirmenin temel unsurları arasındadır ve VUK.113. maddesinde ifade edildiği gibi bu süre geçmesi nedeniyle vergi alacağının kalkması sonucunu doğurur.

Vergi hukukunda zamanaşımının kabul edilmesinin temel nedeni kamu yararıdır. Bundan dolayı borçlar hukukunda farklı olarak kamu düzenini ilgilendirmesi nedeniyle vergi hukukunda re'sen göz önünde tutulur.

Vergi hukukunda iki tür zamanaşımı vardır. Bunlar tarh ve tahsil zamanaşımıdır. Tahsil zamanaşımı ödeme vadesi gelmiş verginin tahsil edebilmesiyle ilgili zamanaşımıdır. Tarh zamanaşımı ise verginin tarh edilerek mükellefe tebliğ edilmesiyle ilgili bulunmaktadır.

Tarh zamanaşımı süresi kural olarak vergi alacağının doğumunu izleyen takvim yılından başlamak üzere beş yıldır. VUK'unda bu genel kural yanında özel tarh zamanaşımı süreleri tespit edilmiştir.

Veraset ve intikal vergisi ile Emlak Vergisinde mükellefiyetin idarece tespit edildiği tarihte başlatılması zamanaşımının amacına uygun düşmemektedir. Çünkü bu durumlarda zamanaşımı süresi bir nevi süresiz

${ }^{41}$ Öncel, Kumrulu, Çağan, s. 136. 
hale gelmektedir. Kamu yararını göz önünde tutarak bu süreler yeniden düzenlenmelidir.

Vergi idaresi takdir komisyonları tarafundan takdir olan matrahlara karşı vergi yargısında dava açabilmektedir. Vergi mahkemelerinde açılan davaların sonucu çoğu kez tarh zamanaşımı dolduktan sonra vergi idaresine gelmektedir. Vergi yargısında matraha karşı açılan davalar nedeniyle tarh zamanaşımının duracağı ile ilgili bir yasal düzenleme bulunmamaktadır. Yasal düzenleme yokluğuna rağmen Danıştay vergi mahkemelerinde matrah takdiri için açılan davalarda geçen sürelerin tarh zamanaşımını durduracağ görüşündedir. $\mathrm{Bu}$ görüş verginin yasallı̆̆ 1 ilkesine uygun düşmemektedir. Çünkü verginin yasallığı ilkesi, vergi kurumlarının hukuksal yapısının temel koşulu olup oranının, salınma biçiminin, alınma zamanının idare ve mükellefler bakımından belirginliğine dayanır. 


\section{KAYNAKÇA}

Akıntürk Turgut. (2006). Borçlar Hukuku. (20. bs.). İstanbul: Beta.

Akkaya Mustafa. (1997). Vergi Sorumlusunun Vergi Yargis1 ve Vergi İdaresi Karşısındaki Konumu. Ankara Hukuk Fakültesi Dergisi. Cilt 46, Say1 1-4,185-208.

Candan Turgut, (2001). Vergilendirme Yöntemleri ve Uzlaşma. Ankara: Yaklaşım Yayınları.

Erginay Akif. (1988). Vergi Hukuku. (13. bs.). Ankara: Turhan Kitabevi.

Kaneti Selim. (1986/1987). Vergi Hukuku. İstanbul: İstanbul Üniversitesi Hukuk Fakültesi Yayınları.

Kırbaş Sadık. (1995). Vergi Hukuku. (7. bs.). Ankara: Siyaset Kitabevi.

Kızılot Şükrü. (2008). Danıştay Kararları ve Özelgeler (Muktezalar). Ankara: Yaklaşım Yayınları.

Mutluer M. Kamil. (2006). Vergi Genel Hukuku. İstanbul: İstanbul Bilgi Üniversiteleri Yayınları.

Şenyüz Doğan. (2008). Vergilendirme Sürecinde Zamanaşımı Kavramı Üzerine Terminolojik Bir Değerlendirme. Tebliğ Zamanaşımı. Yaklaşım Dergisi, 2008/3 (183). 31.08 .2010 tarihinde http://www.yaklasim.com/mevzuat/dergi/makaleler.pdf adresinden erişildi.

Öncel Mualla, Kumrulu Ahmet, Çağan Nami, (2008), Vergi Hukuku, (15.bs.). Ankara: Turhan Kitabevi.

Özyer A. Mehmet. (2008). Vergi Usul Kanunu Uygulaması. (4. bs.). İstanbul: Hesap Uzmanları Derneği.

Ufuk M. Tahir. Veraset ve İntikal Vergisinde Zamanaşımı. Yaklaşım Dergisi. 31.08.2010 tarihinde http://www.yaklasim.com/ mevzuat/dergi/makaleler.pdf adresinden erişildi. 
Uluatan Özhan. (1994). Vergi Hukuku, (2. bs.). Ankara: Adım Yayıncilık.

Ürel Gürol. Şeker Kenan. (2004).Tarh Zamanaşımı ve Defter. Belge İbrazında Özellikli Durumlar. Yaklaşım Dergisi, 2004/2 (134). 31.08.2010 tarihinde http://www.yaklasim.com/mevzuat/dergi/ makaleler.pdf adresinden erişildi.

Yılmaz Kazım. (1994). ABD'de Tarhiyat ve Ceza Zamanşımı. Vergi Dünyası. Say1 155. s.20-32. 